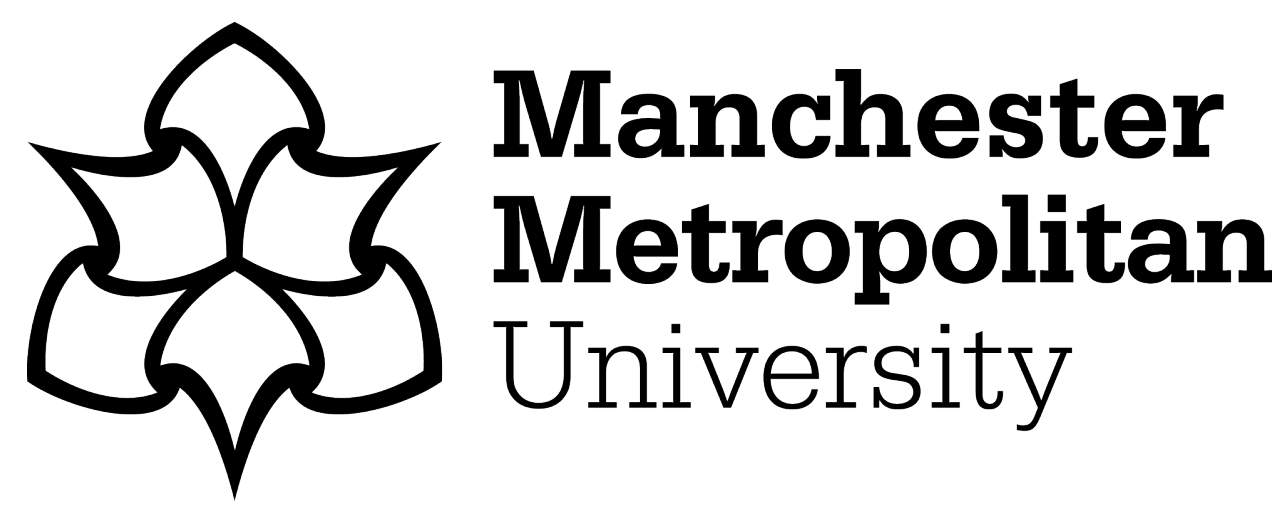

Rowland, Antony (2016) A Dialectic of forgetting: János Pilinszky and Ted Hughes. Comparative Literature, 68 (1). pp. 46-58. ISSN 0010-4124

Downloaded from: https://e-space.mmu.ac.uk/332152/

Version: Accepted Version

Publisher: Duke University Press

DOI: https://doi.org/10.1215/00104124-3462641

Please cite the published version 


\section{A Dialectic of Forgetting: János Pilinszky and Ted Hughes}

Critics such as Michael Parker and Neil Roberts have drawn attention to the influence of Eastern European poetry as a whole on Ted Hughes's work: in Ted Hughes: A Literary Life Roberts points out that "Poets whose work bore witness to the Holocaust and/or Stalinist terror were especially important to him" (179). Initially, Hughes’s attraction to János Pilinszky's verse in particular may seem odd, given its pervasive Christian iconography, and the fact that — as I shall illustrate - the Hungarian poet vacillated between victimhood and complicity during the war. However, Pilinszky's ruminations about trauma and memory strike a particular chord with the Yorkshire poet. ${ }^{1}$ Susan Bassnett, amongst others, has commented briefly on the affinity between the two writers, but in this article I explore the precise impact of Pilinszky on Hughes's writing. ${ }^{2}$ Hughes was working on Pilinszky's poetry with János Csokits in the early 1970s, until the publication of their translations in 1976: at the same time, he was writing two of his own collections that contain similar stylistics; Cave Birds, which he started in 1974, and Gaudete, which he worked on intensively in $1975 .^{3}$ This synchronicity results in two collections that often read as if they were translations. Rather than fulfilling Harold Bloom's magniloquent conception of the anxiety of influence as a violent "family romance" (8) - in which the ephebe vanquishes the predecessor poet in order to survive - the relationship between Hughes and Pilinszky is that of fellow travellers who draw on aspects of each other's work in order to refine previous convictions, rather than subvert the precursor's aesthetics. ${ }^{4}$ Bloom argues that this anxiety implicates a "matrix of relationships-imagistic, temporal, spiritual, psychological," and that all of them are "ultimately defensive in their nature" (xxiii). In contrast, the dialectic of influence that I outline between Pilinszky and Hughes suggests a less antagonistic relationship, despite the fact that, in 1962, the Yorkshire poet referred to influence in Bloomian terms as a kind of contamination. ${ }^{5}$ 


\section{Forgetting János Pilinszky}

In order to ascertain why Hughes singled out Pilinszky's work among that of other Eastern European poets, it is also necessary to ask in what ways the Hungarian author is considered to be a war poet. As I noted in Holocaust Poetry (150), when Hughes writes that Pilinszky was "scooped up" by the retreating German army, it is unclear in what capacity: rather than interned as an "undesirable," Pilinszky was actually a member of an Axis unit. Yet critics often discuss Pilinszky's work without question in the context of other "victim" poets. Michael Parker briefly records Pilinszky's influence on Hughes in relation to Vasko Popa's work — he mentions that Popa fought for partisans in the former Yugoslavia (39) — and Hilda Schiff includes four Pilinszky poems in the "Destruction" section of her $\underline{\text { Holocaust Poetry }}$ anthology, alongside poems by writers who were interned as Jewish inmates, or political prisoners, including Paul Celan, Elie Wiesel, Dan Pagis, Popa, and Tadeusz Borowski (vi). Tibor Tüskés's Pilinszky János alkotásai és vallomásai tükrében-which has not yet been translated into English—-provides more detailed information about Pilinszky's war experiences. After being “scooped up," Pilinszky's unit “is stationed near an airport. They have no weapons; on the airport's runway they are to fill the bomb craters sunk by the English and American fliers, so that the German planes can take off. They do the work together with the Belgian camp inmates; here is where he first meets inhabitants of the death camps". ${ }^{6}$ This episode encapsulates Pilinszky's ambiguous war identity: he is a "perpetrator" — or, at least, complicit—in that he works for the Germans, yet he has no rifle; he is also a victim in the sense that he is toiling under duress, part of a larger work unit that includes camp inmates. ${ }^{7}$ In addition, Ágnes Nemes Nagy notes in The Desert of Love that Pilinszky served as an anti-aircraft gunner in Germany (76), yet Emery George points out that "It was at one time or another thought that [Pilinszky] himself had been interned in one or 
more of [the death camps]": Schiff, for example, records that he "spent some time in [these camps]" (214). ${ }^{8}$

Whereas some critics embellish Pilinszky's war experiences, the poet himself appears to have encouraged a form of forgetting that is central to understanding Hughes's interest in his work. Tüskés relates that when Pilinszky was confronted with questions about his experience, he would reply with oracular calm: “'It's so much beside the point! Tolstoy did not participate in the Napoleonic wars, either!"”9 Pilinszky's undeniable point is that non-participants can produce great art about atrocity, but the response is nevertheless evasive: the complicity of the poet-narrator is central, for example, to an understanding of his war poetry. In "The French Prisoner" from The Desert of Love, the description of an inmate's squashed feet, and his "gibbering, bestial elation," is precise, as an example of primary witnessing, and also discomforting in that ensues from someone who was a member of an Axis unit (30). ${ }^{10}$ Pilinszky iterates metaphors of implication throughout his work: in "Passion," for example, the poet figures butchers' assistants as complicit in their act of washing blood away, which forms an allegorical depiction of enforced forgetting. Similarly, the porkolábparasztok ("turnkey peasants") in his $\underline{\mathrm{KZ} \text {-Oratorio }}$ represent the villagers who would willingly betray others to the SS. ${ }^{11}$ Yet in Conversations with Sheryl Sutton, the Pilinszky character contends —in a similar way to his comments on Tolstoy—that "The war was not something I lived through or suffered through: but it became mine" (23). Even in the context of the elliptical and only semi-autobiographical dialogue in this book, it would appear to be an odd statement, and an aspect of deliberate forgetfulness. Yet it addresses Pilinszky's ambivalence about his war experiences, and his attitude towards testimony: he has clearly "lived" and "suffered" during World War Two, but the judicial categories of victim, perpetrator and bystander cannot adequately account for his position as a witness. He certainly "experienced" the war, but only 
from its periphery; at the same time, he does not entertain the charge of aesthetic larceny when he represents camp inmates, as in the poem I shall now turn to: "The French Prisoner." In a parallel way to the process of Pilinszky's suppression of memory, a fraught dialectic of remembering and forgetting runs throughout this poem. "The French Prisoner" shares with Primo Levi's iconic "Shemà" a depiction of the impossibility of forgetting, but whereas the Italian's poem ends by cursing non-survivors, Pilinszky's begins with a paradoxical plea to forget the victim. At the closure, Pilinszky reveals that the first line- - "If only I could forget that Frenchman"-is actually a quotation from his contemporaneous journal; the poem then overlays the work of primary witnessing like a palimpsest (30). An escapee voraciously eats raw cattle-turnip: his subsequent vomiting links with the involuntary, vomited scream in the first poem of Cave Birds, which I discuss later in this article. Pilinszky then transforms the inmate's action into a vision of the Passion: the simultaneous revulsion and joy becomes a "ravenous ecstasy" (30). As I illustrated in Holocaust Poetry (150-53), Hughes's sensitivity to such moments when—as he puts it his introduction to Pilinszky's work-“the moment closest to extinction turns out to be the creative moment" leads to the lamentable Hughes poem "Lines about Elias," in which Nazi guards enjoy salvation through music. ${ }^{12}$ Yet Pilinszky’s vision is far from comforting: whereas Levi imagines involuntary memory as the albatross from The Rime of the Ancient Mariner, Pilinszky figures the incessant recollection of the Frenchman as an internal canker akin to the tumour in another poem, "World Gone Cold," that here eats away his body with his heart as the ultimate target. In Hughes's translation of Pilinszky's "Harbach 1944," this curse of remembering is further intensified: Emery George translates the repetition of "ujra" with "Again and again [I see the inmates]" (20), whereas for Hughes, the narrator views the death march "at all times."13

Hughes is drawn to this dialectic of memory and forgetting in his poetry of the early 1970s, and in other specific translations of Pilinszky poems that I analyse later in this article: "You 
Have Had to Suffer Rain and Cold" and "Unfinished Past." Indeed, more widely, the dialectic permeates Hughes's literary life: acts of what he perceived to be necessary forgetting — such as the destruction of Plath's last journal, in order to protect his childrencounterbalance his symptoms of mal d'archive in the precarious amassing of his own archives in the early 1990s. In both poets' work, memory and forgetting are also bound up with the shifting categories of perpetrator and victim. So far, I have assumed in my analysis of "The French Prisoner" that the Frenchman is a victim of the Nazis, and that Pilinszky watches the inmate from the perspective of someone also entrapped within the camp system. However, such identities are more ambiguous than they first appear, and connect with the shifting sense of Hughes's protagonist as a victim, and complicit perpetrator, in Cave Birds. Csokits translates "a heves emlék forrón rámkiált" as "the scalding memory roars at me," but Hughes replaces "scalding" with "scorching": the evocation of "scold" in the initial phrase contains an accusation alongside the visceral image that is absent from the final version (31). ${ }^{14}$ The translation of a single word makes the poet-narrator appear on equal terms as the victim in the poem, rather than a potentially complicit voyeur. Another example lies in George's translation of "hajnalfele a szállásunk elött," which retains the word "quarters," as Csokits does in his initial version of "The French Prisoner" (25). As the $O E D$ indicates, "quarters" has the particular connotation of stationed troops, which might hint at Pilinszky's membership of an Axis unit: when Hughes changes the word to "hut," the Hungarian poet attains the same status as the inmate. ${ }^{15}$ The deletion of "quarters" is thus a subsequent act of "forgetting" (or, at least, evasion) in a poem that precisely discusses the vicissitudes of memory.

Metatexual details surrounding the poem are telling in this context, and provide an alternative interpretation of "The French Prisoner." After suffering with chronically swollen legs, Pilinszky entered a United Nations Relief and Rehabilitation Agency near Frankfurt. In 1945, 
Allied forces established UNRRA camps in occupied zones of West Germany for DPs (Displaced Persons): they provided primarily for Jewish inmates, but also others—-such as Pilinszky — who had been obliged to leave their home country. Such camps presumably did not wish to advertise the fact that the latter included soldiers who had fought for, or been enlisted by, the Axis powers. This "forgetting" of potential perpetrators has a profound significance for "The French Prisoner," and the ambiguous identities of the poet-narrator and main character. I have assumed so far that the French prisoner is a camp inmate, and that the guards that take him away are German. Yet Tüskés suggests that the poem is set in the UNRRA camp, and that Pilinszky watches a man who has escaped from French captivity, and whom the American police will then return (84). So, as with Pilinszky's own war identity, the positions of victim, perpetrator and complicit bystander are ambiguous in this poem. As in Tadeusz Borowski's writing about his interment in a former SS camp in Munich, the Americans replace the Germans as the overseers of the DP camps: Borowski recounts how some prisoners were shot when trying to "escape" from their new captors. George further complicates this picture by arguing that the poem's title is (in a positivistic sense) incorrect: Tüskés "is most probably right," he contends, "in mentioning 'French captivity'; that is, it may well have been a French prisoner-of-war camp, which could make the prisoner in the poem a German" (208). Given Pilinszky's resistance to positivism elsewhere through abstract identities - as in his KZ-Oratorio sequence - it is curious that he is so specific in the potentially erroneous title. However, the ensuing ambiguities encapsulate Pilinszky's vacillating positions of victimhood and complicity, and also his autobiographical evasions: in the abstract world of human cruelty in his oeuvre, the victim could sometimes be a member of the Allies or Axis. ${ }^{16}$ This vision of indeterminate identities is central to Cave Birds: the (similarly abstract) protagonist discovers that he is complicit in some way, and must undergo a cathartic process in which he is a victim of a sometimes inexplicable process, but also 
guilty — in terms of his suppression of the feminine — at the same time. ${ }^{17}$ Gripped by the Summoner and Interrogator, he flails under the "angered righteous questions" of the female prosecutor: in "After the First Fright," his rational responses argue him "out of every thought anybody could think," but his irrepressible guilt still persists in the "Catherine wheel in [his] belly" ( Collected Poems 421, 420).

\section{Translating Pilinszky}

Attracted to the politics of memory and "the flower of forgetfulness" in Pilinszky's poetryincluding these shifting identities of victim and perpetrator-Hughes began working more intensely on translations of the Hungarian poet's work in the early 1970 s. ${ }^{18}$ In $\underline{\text { The Poetry of }}$

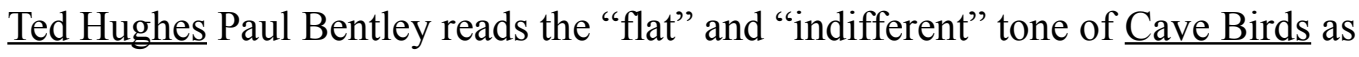
symptomatic of depression (93), but in this article I provide an alternative reading which focuses on the poet's immersion in the Pilinszky translations. ${ }^{19}$ The synchronicity of Hughes

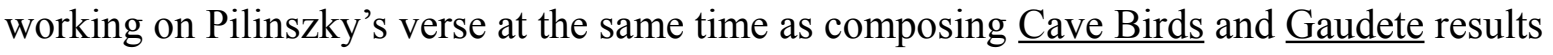
in Hughes poems that sound like Csokits's translations of Pilinszky's verse, and translations that read like poems from these two collections. Deploying Hughes's own diction of influence, Clive Wilmer argues that the introduction to the Hungarian poet's work in The Desert of Love has “contaminated” Pilinszky's oeuvre with Hughes's “apparent inability to depict the poets he admires in terms which do more than reflect his own preoccupations; at times the introduction seems little more than a commentary on Crow" ${ }^{20}$ More generously, the reader might assume that an affinity between the poets results in an introduction, and translations, that explore the shared interests in World War Two, the guilt (and ambiguous identities) of survivors, and how to account for abstract topography with a "direct, flexible, simpler expression" (Letters of Ted Hughes 635). ${ }^{21}$ Wilmer concludes that "Mr Hughes has 
avoided the temptation to impose his own unmistakable cadence and vocabulary on Pilinszky," but the critic must have been thinking here of the author of The Hawk in the Rain and Lupercal rather than the writer of Gaudete and Cave Birds. The "ditches of the deathstruggle" in Pilinszky's "Gradually," for example (The Desert of Love 60), could equally have appeared in the latter two collections, or Crow; indeed, the phrase "death-struggle" features in "After the First Fright" from Cave Birds (Collected Poems 420). Wilmer notes that the rhythms of the translations are "curiously lame" and "prosaic," without making a connection with Hughes's studiously deadened rhythms in the free verse of the Gaudete lyrics

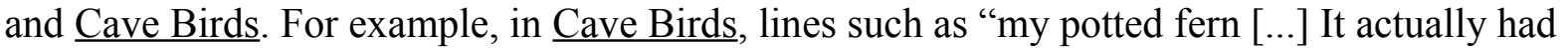
withered" and "a gleam simplification/ Of all that pertained" display linguistic awkwardness akin to a literal translation $(422,429)$. The assured tone and rich language of the early collections has given way to a tentative means of articulation: hence Hughes's exploration in his introduction to Pilinszky's work of a writer who engaged with the temptations of silence. Hughes was impressed with the "spare" language, and enervated rhythms, of Csokits's literal translations of Pilinszky's poems, and left many of them (such as "Apocrypha") without much addition. ${ }^{22}$ Csokits's flatness of tone and economy of style in these translations is replicated not only in Cave Birds, but also in the pastiche of translation in the Gaudete "vacanas": as Hughes writes in a letter to Anne-Lorraine Bujon (16 December 1992) he deployed the "vacanas" style — after reading A.K. Ramanujan's translations in Speaking of $\underline{\text { Śhiva - in order to "reach a more direct, flexible, simpler expression of things" (Letters of }}$ Ted Hughes 635). Hughes's translations of Pilinszky's poems are sometimes more akin to Hughes poems during his minimalist Gaudete phase than the intricately wrought Hungarian originals: a hallmark of Pilinszky's style is his simple, but effective, rhyme schemes and iambic metre, which Csokits and Hughes do not (sensibly) attempt to reproduce. ${ }^{23}$ Such "vacanas" language is not, as Hughes goes on to state to Bujon, constitutive of a lack of 
artifice (Keith Sagar agrees), but is a form of artifice in and of itself. ${ }^{24}$ Pilinszky similarly worked towards an "increasing spareness" and "existential aestheticism" towards the end of his career; these descriptions could apply equally to the poetry of Gaudete and $\underline{\text { Cave Birds }}$ (Metropolitan Icons xxvi).

Pilinszky's "You Have Had to Suffer Rain and Cold" provides an example of this reciprocity between $\underline{\text { Cave Birds, }}$, the epilogue to Gaudete, and the publication of Hughes's translations with Csokits. In The Desert of Love Pilinszky shares a lexicon of abstractions with the poet

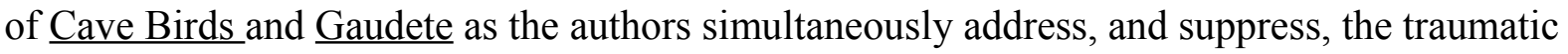
past in visions of the "irreparable, the unacceptable, the unbearable, the unsayable"

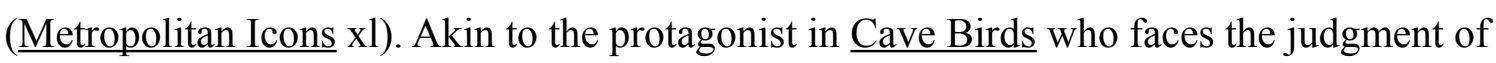
Leonard Baskin's creatures, the speaker in "You Have Had to Suffer Rain and Cold" undergoes a cathartic process in which monsters torment him until he attains a "precarious, blissful moment" towards the poem's closure (20). Just as the sun and vulture torment the plaintiff in "The Interrogator” from $\underline{\text { Cave Birds, }}$ Pilinszky's narrator initially flounders under the rain and monsters' onslaught. Cosmic elements threaten throughout Pilinszky's poetry, such as the mesh of stars in "Fish in the Net" that captures humankind: such imagery pervades $\underline{\text { Cave Birds, }}$, as when the wind, skylines and sun pick apart the conqueror in "The Knight," and a "tarred and starry web" captures the accused in "The Judge" (422). "The Knight" is, in turn, reminiscent of the anatomisation of the protagonist in the $\underline{\text { Crow poems, }}$ and in "You Have Had to Suffer Wind and Rain," the monsters similarly strip the narrator's forehead, eyes and lips until "not a thread" remains (20). "Bride and Groom Lie Hidden for Three Days" from Cave Birds then functions as Bloom's equivalent of the ephebe "completing" the precursor's text in a "corrective movement" (14): Hughes embodies the "precarious, blissful moment" in "You Have Had to Suffer Wind and Rain" in the concretion of the couple bringing "each other to perfection" (Collected Poems 438). The exuberant 
conclusion of "Bride and Groom Lie Hidden for Three Days" is utterly different to the bleak vision at the end of "You Have Had to Suffer Wind and Rain" where, in an arresting image of compassionate complicity, Pilinszky's narrator stands trembling "like a/ burning forest" after the monsters" ravaging. The moon on the wall in "You Have Had to Suffer Wind and Rain" is equivalent to the Summoner in Cave Birds who is attentive to the protagonist's guilt, like a “shadow stark on the wall, all night long" (420). Pilinszky's attendant "convicts condemned to life" at the end of the poem can be read as guilty ponderings as well as the return of victims, like the female accuser in Hughes's “After There was Nothing Came a Woman.” In Hughes's "She Seemed So Considerate" from Cave Birds, the narrator is similarly "condemned to life" in the dream-like world in which the poet's previous existence "has died" (421); he lives on in purgatorial limbo. The image of the convict throughout Pilinszky's poetry functions as veiled autobiography: in "As I Was" from The Desert of Love, a returning convict finds himself speechless in front of a glass of wine, just as Pilinszky is dumfounded when faced with the ravaging aesthetics of a blazing brooch in "Big City Icons." Such moments depict the silent poet that Hughes is so drawn to in his introduction to The Desert of

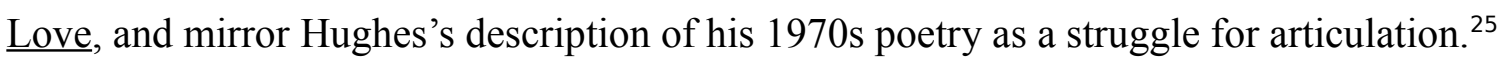

In Pilinszky's "Unfinished Past," the interplay I have outlined above between the poets' work is crystallised in the form of a dedication: this poem illustrates their shared interest in the representation of trauma with "flat" aesthetics. "Unfinished Past" was first published in Viglia in 1957: the epigraph "to Ted Hughes" was inserted over a decade later (Metropolitan Icons 215). Inadvertently, it provides a meta-commentary on the writers' struggles with traumatic experience: the poem describes an unnamed person combing their hair during a stormy night in a mirror, a "coffin of glass" that is "more vigilant than the unfinished past" (45). "Unfinished Past" confronts the same dialectic of memory and forgetting that I outlined in relation to "The French Prisoner," but here in relation to Pilinszky in the early 1950s, and 
—due to the subsequent dedication-Hughes after the "steel doors" of the 1960s shut with the deaths of Plath, Assia Wevill, his daughter Shura, and his mother. ${ }^{26}$ "You" in the poem thus refers to both Pilinszky and Hughes: the act of combing is the equivalent of writing about the traumatic past, a melancholic activity that fixes the authors in the "coffin of glass." "Combing" the past offers the possibility of containment, but the coffin image suggests that the "unfinished past" resists representation, and merely entraps the writer in iteration that is actually an act of concealment. The mirror is "vigilant" in that, in a common and usually unthreatening domestic scenario, it watches the writers' attempts at confronting the past, but the trauma is as uncontainable as the unheimlich flashes of lightening outside the room. Pilinszky's dedication is prescient in that it not only "traps" Hughes in the poem, but also functions as a meta-critical comment on a decade's worth of toil: Hughes would later refer to his 1970 s poetry as a kind of "glass coffin," a confining struggle for articulation that ultimately failed to confront the "steel doors." In a letter to Keith Sagar (18 July 1998) about

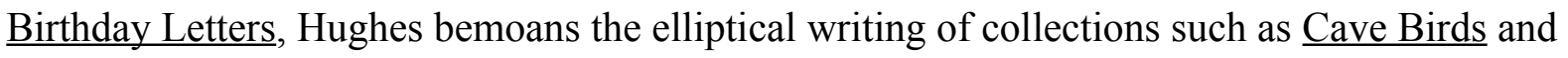
Gaudete as merely diversions, and wishes he had confronted the traumas of the 1960s in a more accessible, testimonial style akin to his last collection (Letters of Ted Hughes $718-26) .{ }^{27}$

Pilinszky depicts this in/articulate grappling with caesurae and stuttering lines: twelve out of the sixteen lines end with a full stop. As in "You Have Had to Suffer Wind and Cold"- such as when the monsters come "up, up crying/ fire" (20)_Pilinszky uses short lines to consolidate the flat tone, and enervated rhythm: Hughes deploys the same technique in $\underline{\text { Cave }}$ $\underline{\text { Birds, }}$, such as in the one- and two-word lines "This bird," "The feet" and "Roots" in "The Plaintiff." Heather Clark detects Sylvia Plath's influence in Cave Birds, particularly in "The Plaintiff's “moon imagery, exclamation points, short lines, and the quickly changing metaphors" (209-10), and yet all of these features are also found in Pilinszky's work: for example, the moon invades the insomniac's room in "Unfinished Past" before the lightening 
features as a violent blow, and then a cataract; "You Have Had to Suffer Wind and Cold" contains six exclamation marks. ${ }^{28}$ Overall, Clark’s argument about Plath's influence on Hughes's work in the 1970s is convincing: outbursts such as "How you have nursed her!" in

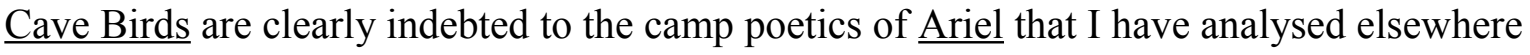
(Holocaust Poetry 28-61). Yet the impact of Pilinszky’s work is of equal importance. Moreover, the influence of Plath and Pilinszky is, as in "The Plaintiff," inextricable, since the poetry of Ariel — with the stylistic quirks that Clark notes above-is so similar to that of The

Desert of Love. In Pilinszky János alkotásai és vallomásai tükrében Tüskés sums up Pilinszky's anti-topographical motifs as including "ice-empty stars," night, dark places and the garments of victims (178): these signs could equally apply to Ariel. Plath's work is thus sometimes indistinguishable from the dialectic of influence between Hughes and Pilinszky. The impact of Ariel on the translations is tangible: the exclamation marks in "You Have Had to Suffer Wind and Cold," for example, are as much a mark of Hughes's internalisation of Ariel's poetics as they are a sign of his attention to the Hungarian original.

\section{"The Scream" and metapoetics}

As the opening poem in $\underline{\text { Cave Birds, }}$, "The Scream" illustrates the influence of the Pilinszky translations I have analysed above on the collection as a whole. The poem embodies the stylistic challenge of the "increasing sparseness" and "existential aestheticism" of Pilinszky's writing to Hughes's poetry before he began publishing his initial $\underline{\text { Crow }}$ poems in 1967, and depicts the eruption of guilt and complicity into the narrator's previously naive existence. ${ }^{29}$ This is not an example of Bloom's "Apophrades," or the "return of the dead," in which the poem is so open to its precursor that it is as if the later poet were the precursor (6), but a meta-critical piece in which Hughes self-consciously writes against the lyrical poetry of The 
Hawk in the Rain and Lupercal. In "Cave Birds: Hughes's Progress of the Masculine Soul," Neil Roberts and Terry Gifford summarise the poem as follows, without reference to the metapoetics: "The tone catches a too-easy acceptance of the nature of things that amounts to glib complacency in its expression. The happy acceptance of the hero's own death is childishly expressed, indicating no distinction between his response to this and his response to what he sees as a world without tensions. What begins as naivety becomes callousness at the point when the hero's response to violent death is a self-satisfied cosmic generalisation" (191). This glibness begins with a life/death dialectic that the protagonist accepts without question: the traumatic sign of the moon on walls in "Unfinished Past" becomes the more benign "sun on the wall" in "The Scream" that is entwined with untroubled dreams of his gravestone (419).$^{30}$ In the second stanza, the nursery picture of the sun then transforms into another example of Hughes's "innocent" artistic endeavours: he evokes the early signature poems of "The Hawk in the Rain" and "Hawk Roosting" with the reference to a hawk perfecting its craftsmanship, just as the predator bird in the latter poem rehearses "perfect kills". ${ }^{31}$ The experience of guilt and complicity in the sequence as a whole subverts these early artistic pursuits: the metapoetics of the first few lines indicate that the Cave Birds poems will be - to take a phrase from the Gaudete lyrics— "libraries/ Of convalescence" (372).

Hughes signals that this change of poetics has occurred due to the guilt registered in the vomited scream at the end of the poem—which results in the narrator's indictment

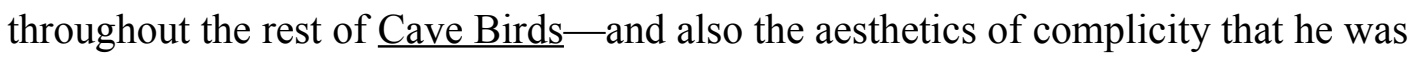
simultaneously working on in the Pilinszky translations. The aesthetics of Hughes's early poems such as "The Hawk in the Rain" and "Hawk Roosting" luxuriate in their own power and singularity: in the former poem, for example, the influence of Hopkins's alliteration and sprung rhythm is pervasive, as in the arresting opening lines "I drown in the drumming 
ploughland, I drag up/ Heel after heel from the swallowing of the earth's mouth" (19). Rather than regard this particular dialectic of influence as a literary strength, however, the narrator of "The Scream" now regards such poems as symptomatic of an innocent "acceptance of the nature of things": this naivety is reflected in the personification of the lazy mountains at the beginning of the poem, which become "mountains of torment" towards the closure of the sequence (419). Tadeusz Różewicz's comment that the entire concept of the aesthetic appeared to him as a childish pursuit after World War Two resonates in the context of the dismissal of Hughes's earlier stylistics. ${ }^{32}$ Różewicz and Pilinszky were suspicious of the lyrical flourish: hence Hughes's prosaic depiction here of worms just doing "a good job," and the switch in register from the calves' heads — in the mind of the younger poet — grinning like masks on a blood-strewn table, to the encounter with death in the form of a friend in a halfcoma, his face covered in stitches after an operation to remove something malignant. ${ }^{33}$ Pilinszky's depiction of a butcher's block washed of blood in "Passion" is akin to the calves' heads, which stand for cosmic equanimity in Hughes's earlier writing, as opposed to the complicity in Pilinszky's poem. Hughes's subsequent image in "The Scream" of the overconfident narrator riding the "wheel of the galaxy" recalls the cosmic imagery of Pilinszky's early poems such as "Fish in the Net". ${ }^{34}$ In another example of the sometimes inextricable influence of Plath and Pilinszky in Hughes's poetry, the "little rabbits" killed in the antecedent line cannot help but evoke the accusations in "The Rabbit Catcher," and Plath's refusal to accept the animals" "little deaths" as simply "the nature of things" (Collected Poems 194).

At the end of the poem, the aesthetics of complicity are registered in the involuntarily vomited scream. Nausea in “The French Prisoner" returns here as Hughes's poetry fragments into Pilinszky and Plath's sparse stylistics: the last stanza, for example, consists of only four words. Tropes of sickness and screaming run throughout Hughes's poetry in the 1970s, as in 
"something was Happening" from Cave Birds, "I heard the screech..." (晶ete) and the vomiting gull in poem 18 from Orts: in “The Scream," the repetition of harsh /d/, /j/ and /v/ sounds accompany the Crow-like image of the scream appearing as an obsidian knife (“obsidean" denotes volcanic rock like bottle-glass). Four- and five-beat lines of early poems such as "Wind" dissipate here into lines that only last for two words. Overall, caesurae predominate, as in "Unfinished Past": nearly half the lines in "The Scream" contain full stops. The flat tone of the Pilinszky translations is particularly marked in the last eleven lines, as the poet enacts the decreasing confidence in the lyrical flourish announced at the beginning of the poem. Csokits declared that these translations were anathema to readers in need of a "verbal soporific or a musical therapy against life": this description accords with the anti-

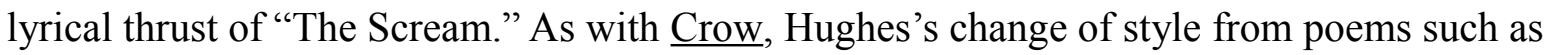
"The Hawk in the Rain" and "Hawk Roosting" was an extraordinarily risky yet astute artistic move, even if Hughes may have felt it was inevitable after the traumatic events of the 1960s, and the increasing influence of the Eastern European poets. No other English poet of the same stature as Hughes in the 1970s—such as Philip Larkin or Seamus Heaney—changed stylistic course so radically mid-career. ${ }^{35}$ Even Geoffrey Hill's Mercian Hymns sequence proved to be a temporary (and brilliant) aberration rather than a permanent foray into "innovative" poetics.

This stylistic direction that Hughes pursued after first encountering Pilinszky's poetry in 1967 petered out after the increasing influence of Seamus Heaney's poetry on Hughes in the late 1970s. ${ }^{36}$ Simultaneously, as Roberts points out in Ted Hughes: A Literary Life, "translation receded from the foreground" of Hughes's concerns after 1977, until the last few years of his life (186-87). ${ }^{37}$ Due to the fact that Gaudete's lyrics and Cave Birds often read like translations, Hughes later ruminated on the "flat" stylistics that are pivotal to the achievement of the collections, but which he can only read, after completion, as an example of studied 
"coldness"; a melancholic iteration that does not free him from the traumas of the 1960s (Ted Hughes: A Literary Life 114). Only the testimonial aesthetics (or, more accurately, antiaesthetics) of Birthday Letters would free him — as he argued just before his death — from these "steel doors" of the 1960s. We now know, from manuscripts deposited in the British Library archives in 2008, that Hughes was working on "The Sorrows of the Deer" (an early title for the Birthday Letters poems) at the same time as the "cold" aesthetics of Gaudete and Cave Birds. In retrospect, Hughes is, by proxy, lamenting Pilinszky's influence on these collections: it results in poems that are potentially too imitative, just "doodling," and too "far off" from what Hughes considers to be his "true" voice. ${ }^{38}$ In contrast, Roberts and many other critics laud Cave Birds and Gaudete as Hughes's finest work: "It is in the period 1973-6," Roberts writes, "that Hughes's work in this decade is truly remarkable" (102). This time span corresponds with the period when Hughes was working on the Pilinszky translations, and the influence of the Hungarian poet was at its strongest. This interaction would have to be deemed unproductively "feminine" in terms of Bloom's model of influence-in which masculine writers struggle with, and against, the precursor—but Hughes and Pilinszky's affinity, and subtle artistic interactions, have lead to some of the most singular poems in Hughes's oeuvre.

Antony Rowland, Manchester Metropolitan University 
1 Michael Parker's groundbreaking essay demonstrates that “A crucial influence on Hughes's poetic development has been the poets of eastern Europe [...] poets who explore themes of profound immediacy to Hughes - survival, death, war, futility, endurance, the cruel ironies of existence" (38). Hughes, of course, co-founded Modern Poetry in Translation with Daniel Weissbort, partly to counteract the insularity of British poetry in the mid to late 1960s. Vasko Popa is the only Eastern European poet who comes close to having the same influence on Hughes as Pilinszky: Hughes provided an introduction to Anne Pennington's translations of Popa's work, which were published by Penguin in 1969. In Winter Pollen Hughes lists Popa as among the "Mid-European" poets who recorded "along with the suffering their inner creative transcendence of it" (221). Similarly to Pilinszky's work, Hughes detects a paring down of language in Popa's poetry, and the formation of tentative new words in response to suffering.

2 In “Travelling Through Translation" Bassnett acknowledges "Pilinszky’s struggle between the will to go on believing in God while simultaneously acknowledging that the horrors exist," and concludes that "in this relationship between the two poets, Hughes confronts his own demons" (10).

3 For the dates of composition, see Ted Hughes, Collected Poems (1263, 1267). Season Songs was also published during this period (1976). In Poet and Critic: the Letters of Ted Hughes and Keith Sagar Hughes writes (28 December 1981) that his poetry of the 1970s was composed in different ways for various people: "It's a mistake," he concludes "to write for this audience (Season Songs) or that audience (Elmet) or that other (Cave Birds). It's one of the temptations of writing for a living” (116). Pilinszky thus influences a particular strand of Hughes's writing, exemplified by

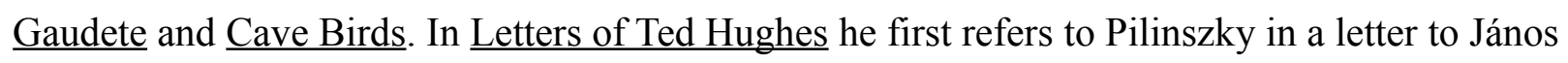
Csokits (6 August 1967) in which he mentions that "Pilinzky [sic] is in London-Olwyn met him \& liked him extremely" (275). Olwyn Hughes then acted as an agent for Pilinszky’s work. Reid notes 
that "it seems that he and TH were yet to meet" (275). In Metropolitan Icons: Selected Poems of János Pilinszky in Hungarian and English Emery George records that they met for the first time at the Poetry International conference in London in 1969 (215). A photograph in the British Library archives shows Pilinszky alongside the other international poets at the conference (W.H. Auden, Edward Braithwaite, Ogden Nash, Anthony Hecht and Vasko Popa), and Robert Bly holding court in what appears to be a small carpet (Add Ms 88984/6/54). In a letter to Csokits (28 May 1974), Hughes discusses the introduction to their translations, and states that he has been "living" with Pilinszky's poems since at least 1967, " $\&$ they are still as interesting $\&$ still seem as good as ever" (Letters of Ted Hughes 351). This date concurs with Csokits's assertion in "Notes on Translating János Pilinszky" that The Desert of Love was the fruit of “our nine year labour" (1967-76), although the early 1970s marked an increasing intensity in their work (Emory archives: "Ted Hughes: Notes on Translations").

4 Bloom does concede (in the new preface) that the influence process is still "dark ground" in most areas (xi), and so, by implication, might not always follow his determinist model.

5 In a letter to Ben Sonnenberg (2 July 1962), Hughes ruminates that "To be influenced is perhaps evil, or rather the weakness in us that permits any influence but for our further true development, is evil, but it's better destroyed quickly, if we are weak, than go on protecting our inanity with deliberate cautious ignorance" (Letters of Ted Hughes 202). In his preface, Bloom similarly refers to influence as a "horror of contamination" (xxiv). This "horror" usually appertains to a young poet, according to Bloom, "discovering his own incurable case of continuity" (62). This model would have to be refined in relation to Hughes's career, since his anxiety of influence increases as he ages. Hughes had a clear sense of who his precursors were (Blake, Beethoven, Yeats and Hopkins, mainly) from a precociously early age, whereas he becomes wary of outside "contaminations": 
hence his discussions with William Scannell over whether Plath's writing influenced his own (Ted Hughes, letter to Bill [William Scammell] (29 April 1998), from the Hughes papers in the British Library (Add. MS 88918/137)). His anxiety also increases over other writers drawing on his own work, in relation to Plath most famously, but also in relation to writers such as Philip Larkin, as I discuss in The Revision of Englishness (81-94). Hughes also does not appear to register when his own ephebes, such as Simon Armitage, begin to define Hughes himself as an original poet, and an escapee, in Bloom's terms, from the anxiety of influence.

6 See George (xxi).

7 I am conscious of trying not to impose the sanctity of the present on a complex situation during wartime. In a different context, Latvian soldiers, for example, fought in German uniform (in this case, against the Russians) during World War Two. The judicial categories of perpetrator, victim, and complicit bystander cannot adequately account for Pilinszky's, and the Latvian soldiers', situation.

8 When Pilinszky did visit Auschwitz I with his sister in 1965, he was particularly struck by the piles of spectacles, utensils and suitcases: he mentions them in "The Fate of the Creative Imagination in our Time" and "Where Poetry Counts" (Emory archives: Subseries 2.7). In the latter, he writes that the utensils "have become the relics peculiar to our century. Without exception they carry clear and distinct marks: traces of blows and of wear and tear --- symbols of our century --that we have not tried to decipher: they are the hieroglyphs of our age" (2).

9 See George (xx). 
10 Pilinszky's war poetry is singular in that it does not display the common characteristics of "victim" poems that I analyse in Poetry as Testimony: Witnessing and Memory in Twentiethcentury Poems, such as a plea for the hyperattentiveness of the reader, a self-conscious struggle for articulation, or resistance to identification (1-16). This singularity may be precisely due, however, to the poet-narrator's attempt to suppress his own identity in the poem, as a member of an Axis unit.

11 See George (218). KZ-Oratorio: Dark Heaven was first performed at the József Katona Gimnázium in Kecskem ét in the spring of 1963. In relation to "Passion," George writes that "as Pilate washed his hands of Jesus [...], so do the numerous 'butcher's assistants,' that is, petty bourgeoisie who helped run the camps, once again feign innocence and pretend they knew little or nothing of what they helped make possible" (222).

12 More positively, "In These Fading Moments I Wanted to Say” from Cave Birds forms a palinode to "Lines about Elias." "Fading," the narrator focuses on the aesthetics of the scree slipping and trickling, and the snow melting "Through its anaesthetic," but the poem ends not with exculpation, as with "Lines about Elias," but the apocalyptic image of the earth turned to the wall in its bed (Collected Poems 424).

13 My italics.

14 For the original Hungarian, see George 26. 
$15 \underline{\text { OED }}, 2^{\text {nd }}$ edn.

16 These vacillations are also in evidence in "Frankfurt." On a first reading, it appears that Pilinszky depicts himself as a ravenous inmate akin to the French prisoner who devours the rubbish when it is delivered to a waste site. However, the line "the first surge of hunger overwhelmed us" is ambiguous: it could refer to the deliverers of refuse, including Pilinszky, or the attendant horde that devours "gristles of the offal" (The Desert of Love 34). Tüskés makes it clear that Pilinszky "was decently fed [in the UNRRA camp], implying that he was thus not subject to the humiliations he depicts" (209).

17 Rand Brandes argues that Gaudete too is "an attempt to come to terms with Sylvia Plath's suicide, a death that can be read as a synecdoche for his attempt to come to terms with all that is 'feminine' in society and the world" (184).

18 The phrase is Freud's, from Jensen's “Gradiva" and Other Works (40).

19 In a letter to Hughes (6 October 1976), Pilinszky discusses his own struggles with depression: "Je suis de nouveau dans une clinique psychiatrique. Depression. Mais ça va de nouveau un peu mieux" (Again I'm in a psychiatric clinic. Depression. But again I'm feeling a bit better) (Emory Archives: B6 F7 Ted H Series 1.1 János Pilinszky). Later letters (8 December 1976; 13 January 1978; 21 November 1978) also ruminate on his mental illness.

20 In turn, Pilinszky was working on translations of $\underline{\text { Crow }}$ when he died in 1981. The Emory archives include a letter (8 December 1976) in which Pilinszky proposes this project to Hughes: 
“J'aimerais faire un livre (Poèmes choisis) en Hongrois de Toi. Pourrais-tu m’envoyé un choix, ou tu préférais la troduction intégrale de Crow?" (I would like to do a book (Selected Poems) of yours in Hungarian. Would you be able to send me a choice, or would you prefer the whole translation of Crow?) (Emory Archives: B6 F7 Ted H Series 1.1 János Pilinszky).

21 In a letter to Hughes (5 August 1976), Pilinszky expresses his delight after reading the introduction: "Ton préface est le premier analyse valable jusqu'ici concernant ma „pouvre” poésie” (Your preface is the first decent analysis as far as my 'poor' poetry is concerned) (Emory Archives: B6 F7 Ted H Series 1.1 János Pilinszky).

22 In an article in Poetry Nation Review Daniel Weissbort notes that Hughes urged his publishers to "accord equal status to Csokits," describing him as the latter's "troubled mechanic" rather than “co-pilot." Roberts illustrates that Hughes sometimes "finds a word that more vividly or powerfully conveys the meaning gestured at in Csokits's version" (185) (Emory Mss. 644, Box 131 folder 32/21/30/24, 45). One example is the "“featureless man of basket" in Pilinszky's "By the Time You Come," which becomes the "brilliant "lumpish basketwork dummy" that "combines connotations of 'featureless' and 'inarticulate,' keeps the literal meaning of the second word, and is much more vigorous and idiomatic than Csokits's phrase" (185). Other examples include Hughes's reaction to the literal phrase "tremor" in "Trapeze and Parallel Bars" (The Desert of Love 18). Csokits's note in the manuscripts requests that an equivalent phrase must be applicable to the wings of birds, eyelids or leaves; Hughes inserts “flutter” (18).

23 In a letter to Lajos Koncz (2 April 1975), Hughes emphasises that he focused on Pilinszky’s tone in the translations, since he knew "no Hungarian," so "The real excellences of Pilinszky—the peculiar qualities and tensions of his language, and his technical form [...] are beyond me, naturally, 
and obviously cannot be approximated” (“Ted Hughes and János Pilinszky” (2)). Pilinszky’s "greatness," Hughes declares, 'seems to touch [him] very closely" (2).

\section{The Art of Ted Hughes (224).}

25 See his comments about “doodling” in the letter to Lucas Myers (28 December 1981) (Letters of Ted Hughes 450), and his discussion about his "rough \& ready counters of language" in a letter to Keith Sagar (11 March 1981).

26 In a letter to Lucas Myers (29 December 1984), Hughes refers to the events of 1963 and 1969 as like "giant steel doors shutting down over great parts of myself" (Letters of Ted Hughes 489).

27 Hughes wonders if a "much much earlier" attempt to "complete a full account, in the manner of those BL, of that part of my life, would not have liberated me to deal with it on deeper, more creative levels" (718).

28 "The mouth wounds, the tongue flames" in "The Plaintiff" are also reminiscent of the heart wound and Pentecostal "late mouths" in Plath's "Poppies in October" (Collected Poems (240)). The image of traumatic memory as a blow is particularly resonant in the context of Hughes description in 1998 of his inability to deal with the "steel doors" as leading to "a recurrent stuck dream," like the nightmare world of "Unfinished Past," that "simply goes on delivering its inescapable blow" (Letters of Ted Hughes 718). 
29 Hughes begins working on the Crow poems around the same time that he first encounters Pilinszky's verse. I have argued elsewhere for the influence of Pilinszky's writing on the Crow poems (Holocaust Poetry 162-3). In a letter to Neil Roberts and Terry Gifford (29 October 1978), Hughes argues that the guilt in the poem is specifically "the extraverted, beady-eyed, predatory career of the organism making its way, clearing its space and setting up its fort and satisfying its needs" (Letters of Ted Hughes 396).

30 It is unclear whether the sun on the wall constitutes an actual nursery picture, or whether the abstract sun on the wall is representative of the narrator's childhood.

31 "The Hawk in the Rain" was first published as "The Hawk in the Storm" in Atlantic Monthly (1957), and "Hawk Roosting" appeared initially in The Grecourt Review in 1959 (Collected Poems $1241-2 ; 1244)$.

32 See my comments on Różewicz in Poetry as Testimony 40, 53. In an obituary for Różewicz in The Guardian, Katarzyna Zechenter comments that his poems were "ascetic, without metre, rhyme or metaphors, stripped bare of any rhetorical posturing and ornamentation and anything that could be considered aesthetically pleasing" (53).

33 In a letter to Craig Raine (23 February 1984), Hughes argues that this vision prefigured, "3 years early," "Leonard [Baskins's] operation" (Letters of Ted Hughes 480). 
34 The references to nothingness, the void, elements, stones, dying, writhing, suffocation, cries, fighting, killing, suffering and hell in "Fish in the Net" constitute the linguistic terrain of Cave Birds and $\underline{\text { Crow. }}$.

35 An equivalent would be Robert Lowell's change of style in Life Studies.

36 More work needs to be done on the interaction between these two writers, but Clark does note that Hughes's move away from the "esoteric motifs and surrealism" of $\underline{\text { Cave Birds and Gaudete }}$ "may have been inspired by his reading of Seamus Heaney. Though Moortown was published in 1979, many of the poems in this collection date from the early- to mid-seventies. Hughes would have read Heaney's Death of a Naturalist (1966) [by this time]" (218). In turn, Heaney famously credited Hughes's "View of a Pig" as "one of the poems that inspired him to begin writing" (218).

37 Although Hughes remained interested in translation throughout his career, a late interest in translations certainly flourished, with his work on Ovid, Racine, Euripides and Aeschylus.

38 In a letter to Lucas Myers (28 December 1981), Hughes writes that "for the last ten years I've just piddled about - everything except make a stand and confront the real thing in a concentrated way. Everything except concentrate and confront. What I've written in these years is all doodle somehow-I just never put myself behind it [...] Since 1970 I've written nothing of what I feel I should have and could have [...] It's been a ten years of odd estrangement from myself" (Letters of Ted Hughes 450). 


\section{Works Cited}

Bassnett, Susan. “Travelling Through Translation.” Comparative Critical Studies 6:1 (2009): 7-19. Print.

Bentley, Paul. The Poetry of Ted Hughes: Language, Illusion and Beyond. Harlow: Longman, 1998. Print.

Bloom, Harold. The Anxiety of Influence. 1997. Oxford/New York: Oxford University Press, 2003. Print.

Brandes, Rand. “The Economy of Flesh in Ted Hughes's Gaudete.” Critical Essays on Ted Hughes. Ed. Leonard Scijay. New York/Don Mills: Macmillan, 1992: 172-87. Print.

Clark, Heather. The Grief of Influence: Sylvia Plath and Ted Hughes. Oxford: Oxford University Press, 2011. Print.

Freud, Sigmund. Jensen’s “Gradiva” and Other Works. Trans. James Strachey, in collaboration with Anna Freud. Great Britain: Vintage: The Hogarth Press and the Institute of Psychoanalysis, 2001.

Print.

Hughes, Ted. Collected Poems. Ed. Paul Keegan. London: Faber, 2003. Print.

Hughes, Ted. "Vasko Popa.” Winter Pollen: Occasional Prose. 1969. Ed. William Scammell. London: Faber, 1994. Print.

Koncz, Lajos. The Hungarian Quarterly xliv, 171: Autumn 2008: 1-2. Print.

Letters of Ted Hughes. Ed. Christopher Ricks. London: Faber, 2007. Print.

Metropolitan Icons: Selected Poems of János Pilinszky in Hungarian and English. Trans. and ed. Emery George. Lewiston: The Edwin Mellen Press, 1995. Print. 
Nagy, Ágnes Nemes. “János Pilinszky: a Very Different Poet.” The Desert of Love: 73-79. Print.

Parker, Michael. "Hughes and the poets of Eastern Europe." The Achievement of Ted Hughes.

Manchester: Manchester University Press, 1983: 37-51. Print.

Pilinszky, János. Conversations with Sheryl Sutton: the Novel of a Dialogue. Manchester: Carcanet, 1992. Print.

Pilinszky, János. The Desert of Love: Selected Poems. 1976. Trans. János Csokits and Ted Hughes. London: Anvil, 1989. Print.

Pilinszky, János. "The Fate of the Creative Imagination in our Time” and "Where Poetry Counts" (Emory archives: Subseries 2.7).

Plath, Sylvia. Collected Poems. London: Faber, 1981. Print.

Roberts, Neil and Gifford, Terry. "Cave Birds: Hughes's Progress of the Masculine Soul.” Critical Essays on Ted Hughes: 188-204.

Roberts, Neil. Ted Hughes: A Literary Life. New York: Palgrave, 2006. Print.

Rowland, Antony. "A case of red herrings: Englishness in the poetry of Philip Larkin and Ted Hughes." The Revision of Englishness. Ed. David Rogers and John McLeod. Manchester and New York: Manchester University Press, 2004: 81-94. Print.

Rowland, Antony. Holocaust Poetry: Awkward Poetics in the work of Sylvia Plath, Geoffrey Hill, Tony Harrison and Ted Hughes. Edinburgh: Edinburgh University Press, 2005. Print.

Rowland, Antony. Poetry as Testimony: Witnessing and Memory in Twentieth-century Poems. New York: Routledge, 2014. Print.

Sagar, Keith. The Art of Ted Hughes. Cambridge: Cambridge University Press, 1978. Print. 
Sagar, Keith. Poet and Critic: the Letters of Ted Hughes and Keith Sagar. London: the British Library, 2012.

Schiff, Hilda, ed. Holocaust Poetry. London: HarperCollins, 1995. Print.

Tüskés, Tibor. Pilinszky János alkotásai és vallomásai tükrében. Budapest: Szépirodalmi, 1986.

Print.

Weissbort, Daniel. “The Troubled Mechanic: Ted Hughes and Translation.” Poetry Nation Review 168 (32: 4): March/April, 2006 (accessed via the Carcanet Archive (16 April 2014) at www.carcanet.co.uk).

Wilmer, Clive. “A Net of Stars.” Poetry Nation Review 3 (4: 3): April/June, 1978 (accessed via the Carcanet Archive (16 April 2014) at www.carcanet.co.uk).

Zechenter, Katarzyna. Obituary for Tadeusz Różewicz. The Guardian. 10 May 2014: 53. 
